\title{
Bacterioplankton growth yield in continuous seawater cultures*
}

\author{
Peter Koefoed Bjørnsen \\ Freshwater Biological Laboratory, Helsingørsgade 51, DK-3400 Hillerød, Denmark
}

\begin{abstract}
Estuarine planktonic bacteria were grown in gas-tight continuous cultures on filtered seawater with reduced content of inorganic carbon. Production of $\mathrm{CO}_{2}$ (respiration) and of particulate organic matter (net production) were measured by infrared gas analysis, and growth yield was calculated as net production divided by the sum of respiration and net production. Cultures grown at 6 , 10 and $15^{\circ} \mathrm{C}$ showed an average growth yield of $20.7 \%( \pm 1.1,95 \% \mathrm{CL}$ ) with minor correlations to both temperature and generation time. This value is considerably lower than the generally assumed growth yield of $60 \%$, based on short term uptake of radiolabelled substrates. Bacterioplankton gross production and substrate demand might thus have been severely underestimated in previous studies.
\end{abstract}

\section{INTRODUCTION}

The past decade has provided us with a new view on the trophic role of planktonic bacteria. While traditionally regarded as mineralizers exclusively of particulate detritus (Lindemann 1942, ZoBell 1946, Steele 1974, Stevenson 1978), bacterioplankton are now believed to recycle large amounts of dissolved organic matter back to the food web, efficiently and rapidly (Pomeroy 1974, Williams 1981, Taylor 1982, Azam et al. 1983).

A carbon conversion efficiency of $60 \%$ for bacterial growth has been accepted as a general mean (Calow 1977), though values of $50 \%$ (e.g. Azam et al. 1983) and $70 \%$ (Williams 1981) have also been adopted. These values are all based on determinations of bacterial uptake and respiration of radiolabelled substrates during a few hours incubation. However, the conversion efficiency of simple substrates is not necessarily identical to the overall growth yield on complex natural substrates.

The aim of this study was to evaluate the bacterial carbon conversion efficiency by a direct method, independent of the radiotracer methods. Hagström et al. (1984) demonstrated that it is possible to grow mixed bacterioplankton assemblages in continuous cultures on filtered seawater for several generations. By combining this approach with the sensitive infrared gas analysis of dissolved inorganic carbon (DIC) and parContribution No. 443 from the Freshwater Biological
Laboratory

(c) Inter-Research/Printed in F. R. Germany ticulate organic carbon (POC), it was possible to assess the growth yield during steady state growth in unenriched seawater cultures.

\section{MATERIALS AND METHODS}

Inocula and media. Water for inocula and media preparation was sampled from the eutrophic estuary Roskilde Fjord, Denmark, on 11 March, 29 April and 3 July, 1985.

Water for inocula preparation was filtered through $1 \mu \mathrm{m}$ Nuclepore filters and treated with cycloheximide (25 $\mathrm{mg} \mathrm{l}^{-1}$ ) for $2 \mathrm{~h}$ to kill eucaryotes (Fuhrman \& McManus 1984). A $25 \mathrm{ml}$ subsample was used as inoculum for each culture.

Water for media preparation was filtered through Whatman GF/C-filters within $6 \mathrm{~h}$ of sampling. The amount of $\mathrm{HCl}$ required for conversion of all inorganic carbon to free $\mathrm{CO}_{2}$ was estimated from measurements of $\mathrm{pH}$ and total DIC, and this amount was added to $5 \mathrm{l}$ subsamples. The acidified water was bubbled with $\mathrm{CO}_{2}$-free air for 1 to $3 \mathrm{~h}$. This procedure was repeated twice until total DIC was below $0.05 \mathrm{mM}$. The water was then adjusted to $\mathrm{pH} 8.0$ with a dilute phosphate buffer $\left(0.1 \mathrm{~N} \mathrm{NaOH}\right.$ and $\left.0.01 \mathrm{~N} \mathrm{Na} \mathrm{NaO}_{4}\right)$, filtered through a $0.2 \mu \mathrm{m}$ Gelman Minicapsule filter and stored frozen. Inorganic nitrogen and phosphorus were present in quantities in excess of the bacterial requirement (Geertz-Hansen pers. comm.), so the cultures were presumably carbon limited. 


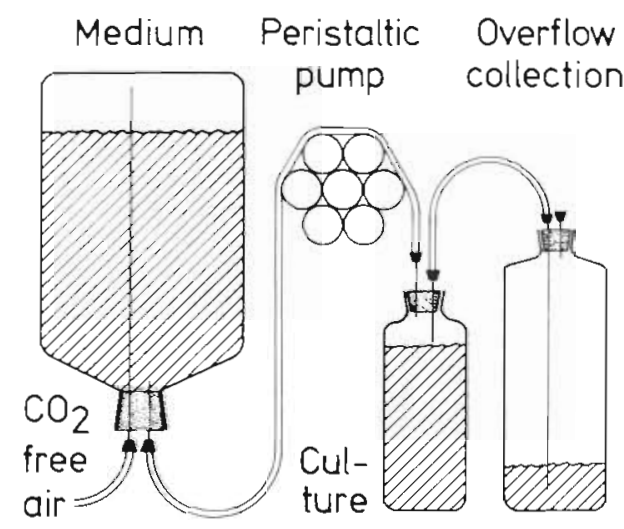

Fig. 1. Experimental set-up

Continuous culture system. The gas-tight culturing system was constructed from glass bottles, anaerobic butyl rubber stoppers (Bellco), stainless steel canullae and Tygon tubing $(0.8 / 2.4 \mathrm{~mm})$ (Fig. 1). Two or 3 parallel $500 \mathrm{ml}$ culture bottles were incubated in a shaking bath at ambient temperatures. During the last 2 experiments, mild ultra-sonification was applied to the water bath to prevent wall growth and cell clumping. Medium inflow to the culture bottles was controlled by peristaltic pumps. Drip-feeding through the head spaces of the culture bottles prevented back-growth into the medium bottle. The outflow worked as an overflow controlled by the head space pressure. The overflow was collected in $\mathrm{HgCl}_{2}>5$ ppm final concentration). The cultures were allowed to grow up as batches before the flow was turned on. At least 2 generation periods were run before the first sampling. A series of flow rates was run for each culture and for each flow rate at least 1 generation period or $1 \mathrm{~d}$ was awaited before sampling.

DIC and POC determination. Samples for DIC determination were taken from medium and culture bottles with $1 \mathrm{ml}$ syringes. Triplicates of $100 \mu \mathrm{l}$ were injected into a chamber containing $3 \% \mathrm{HNO}_{3}$, bubbled by a nitrogen flow which led the released $\mathrm{CO}_{2}$ to an infrared gas analyser (ADC model $225 \mathrm{MK} 3$ ). The signal was integrated over a period of $75 \mathrm{~s}$ from injection of sample. The measurements were calibrated with solutions of $\mathrm{KHCO}_{3}$.

Samples for POC analysis were taken from medium and overflow accumulation bottles. Triplicate subsamples of 25 or $50 \mathrm{ml}$ were filtered onto Whatman GF/F filters, using a minimum vacuum $(<1 \mathrm{~cm} \mathrm{Hg})$. To reduce background, the filters were wet oxidized by $100 \mathrm{mM} \mathrm{K}_{2} \mathrm{Cr}_{2} \mathrm{O}_{7}$ in $60 \% \mathrm{H}_{2} \mathrm{SO}_{4}$ at $140^{\circ} \mathrm{C}$ for $3 \mathrm{~h}$. After filtration of samples the filters were rinsed 5 times by $1 \mathrm{ml} 0.2 \mu \mathrm{m}$ filtered distilled water and dried at $60^{\circ} \mathrm{C}$ for $15 \mathrm{~min}$. The dry filters were combusted at $650^{\circ} \mathrm{C}$ in a quartz tube furnace in an oxygen flow passing to the infrared gas analyser. Samples of the medium were used as blanks (see below). The measurements were calibrated by solutions of glucose pipetted onto furnaced glass fibre filters. Recovery was tested on bacterioplankton batches incubated with ${ }^{14} \mathrm{C}$-glucose ( $4 \mu \mathrm{Ci} \mathrm{l}^{-1},<16 \mathrm{nM}$ ) for several generations to achieve homogeneous labelling. Samples of $25 \mathrm{ml}$ were run through the procedure described above. The radioactivity of filters before and after combustion was related to a reference activity of unfixed samples of $10 \mathrm{ml}$ filtered onto $0.45 \mu \mathrm{m}$ cellulose nitrate filters. Radioactivity was assayed by liquid scintillation counting with external standard quench correction. Recoveries at 6,10 and $15^{\circ} \mathrm{C}$ were $0.88 \pm 0.03$, $0.95 \pm 0.02$ and $0.82 \pm 0.05$ (means and standard deviations of triplicates). These values differed significantly $(\mathrm{P}<0.05)$ and were therefore used separately in further calculations. The high retention efficiency of the wetoxidized GF/F filters was confirmed by epifluorescense microscopy on the filtrate. Cell number was determined by epifluorescense microscopy on acridine-orange stained samples (Hobbie et al. 1977).

Calculations. The growth yield (Y) was calculated according to the formula:

$$
Y=\frac{\Delta \mathrm{POC}}{\triangle \mathrm{POC}+\triangle \mathrm{DIC}}
$$

where $\triangle P O C=$ the difference in particulate organic carbon between medium and overflow collection bottles; $\triangle D I C=$ the difference in inorganic carbon between medium and culture bottles, corrected for leakage of $\mathrm{CO}_{2}$ through the Tygon tubing $\left(38 \mu \mathrm{g} \mathrm{Ch} \mathrm{h}^{-1}\right.$ $\left.\mathrm{m}^{-1}\right)$.

\section{RESULTS}

The continuous cultures could be run for several weeks with generations times (defined as the inverse of the dilution rate) ranging from 1 to $10 \mathrm{~d}$. The carrying capacity decreased from the first to the last experiment (Fig. 2), as did the chlorophyll a concentration in situ (author's unpubl. data). The cell number per ml reached $32 \times 10^{6}, 10.7 \times 10^{6}$ and $2.0 \times 10^{6}$ during the 3 experiments, corresponding to bacterial biomasses of 39, 50 and $71 \mathrm{fg} \mathrm{C} \mathrm{cell}{ }^{-1}$, respectively. Most of the literature on bacterioplankton biomass has reported lower values of carbon content per cell (e.g. Ferguson \& Rublee 1976, Watson et al. 1977). However, these values, which are based on theoretical assumptions on density and dry matter content of the cells, might be underestimated by a factor of 2 to 5 (Bratbak \& Dundas 1984, Bratbak 1985, Bjørnsen in press). As expected from the theoretical chemostat model (Slater 1979), the measured productions of particulate organic carbon (POC) and $\mathrm{CO}_{2}$ (DIC) seemed to decrease at short generation times (Fig. 2, upper panels). 

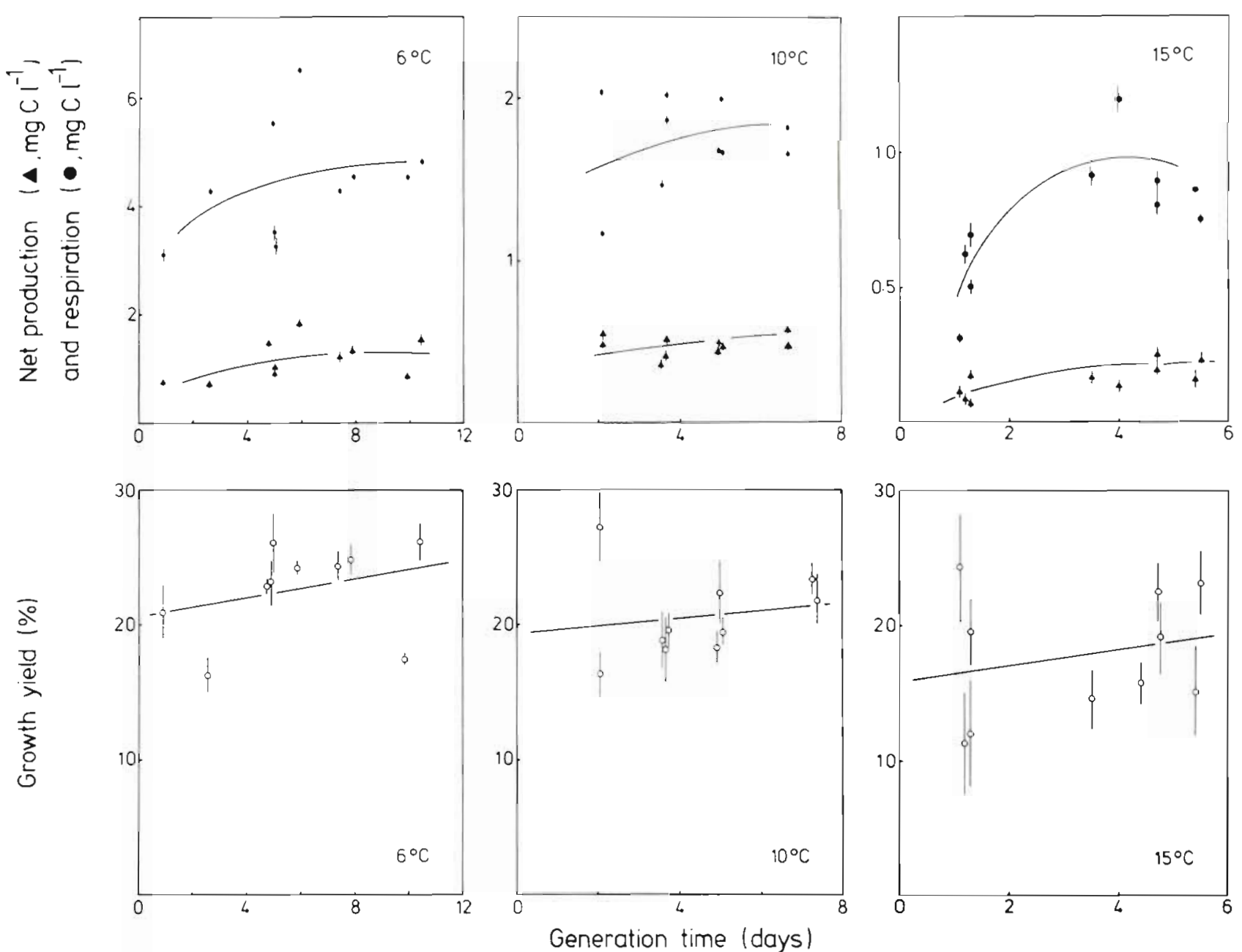

Fig. 2. Carbon balances for continuous seawater cultures grown at varying generation times (abcissae, d) and at 3 different temperatures. Upper panels: produced concentrations of particulate organic carbon (net production, $\mathbf{4}$ and of dissolved inorganic carbon (respiration, $\bullet$ ) in terms of $\mathrm{mg} \mathrm{Cl}^{-1}$ Lower panels: calculated growth yields (net production divided by the sum of net production and respiration, 0 ). Bars indicate SEM of triplicates

The calculated growth yields ranged between 11 and $27 \%$ with an overall mean of $20.7 \%( \pm 1.1,95 \%$ CL). In each of the 3 experiments the growth yield increased with increasing generation time (Fig. 2, lower panels). From the theoretical chemostat model we should expect decreasing growth yields with increasing generation time (Slater 1979) due to a constant carbon demand for maintenance. However, the model is restricted to 1 -species systems, while the continuous cultures were run with mixed populations. The observed pattern might therefore be caused by selection for resource conservation (species with high growth yields) at high generation times. The 3 correlations were insignificant $(\mathrm{P}>0.05)$ when tested separately by linear regression.

The mean carbon conversion efficiency was negatively correlated to temperature $(\mathrm{P}<0.01$, Fig. 3$)$. This correlation is consistent with previously observed annual variations in bacterial carbon conversion effi-

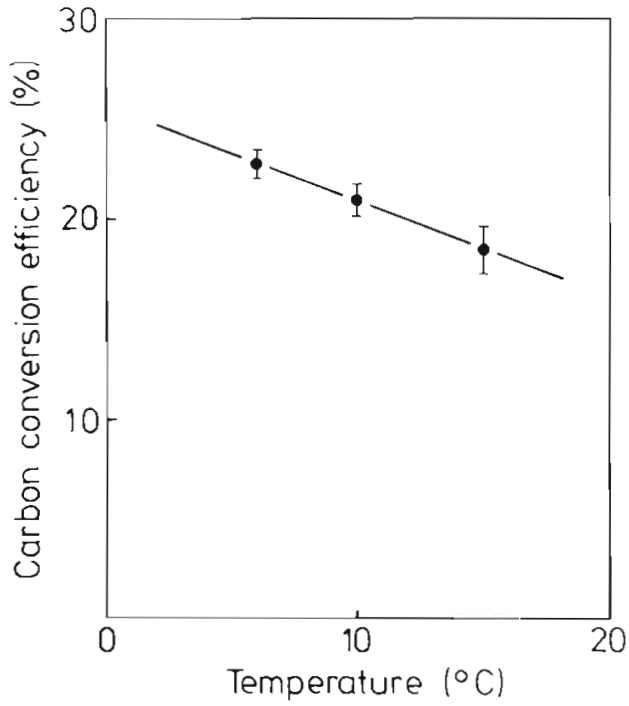

Fig. 3. Mean growth yield (cf. Fig. 2) as a function of temperature. Bars indicate SEM 
ciency (Gocke 1976, Keller et al. 1982). However, the 3 experiments were carried out at different seasons with different media and bacterial populations, so several factors might have influenced the growth yield.

The experiments were intended to mimic limited growth under natural conditions, but some manipulations had to be introduced. A reduction of background content of inorganic carbon was necessary to obtain DIC measurements with sufficient precision. No difference in carrying capacity was observed between cultures grown on media with reduced and with natural contents of inorganic carbon. The addition of cycloheximide to the inocula was intended to kill eucaryotic bacteriovores that might have passed the $1 \mu \mathrm{l}$ Nuclepore filter (Fuhrman \& McManus 1984). In fact, no flagellates were observed during examination of the cultures by epifluorescence microscopy. Fresh solutions of cycloheximide $\left(10 \mathrm{mg} \mathrm{l}^{-1}\right)$ caused an immediate reduction of bacterial activity (assessed by ${ }^{3} \mathrm{H}$ thymidine incorporation) of less than $25 \%$. On the other hand, batch cultures inoculated with cycloheximide-treated $1 \mu \mathrm{m}$ filtrates revealed about $20 \%$ higher carrying capacities than parallel batches with untreated inocula.

\section{DISCUSSION}

The bacterioplankton growth yields obtained in this study showed a pronounced discrepancy from the gen- erally applied values of 50 to $70 \%$ (Calow 1977, Williams 1981, Azam et al. 1983). Those high conversion efficiencies are based on numerous studies, in which samples of natural bacterioplankton were incubated with tracer amounts of ${ }^{14} \mathrm{C}$-labelled organic compounds (Table 1). After incubation, typically a few hours, particulate uptake of ${ }^{14} \mathrm{C}$ was compared with respired ${ }^{14} \mathrm{CO}_{2}$. This approach has revealed short term conversion efficiencies of about $70 \%$ for glucose and various amino acids (reviewed in Joint \& Morris 1982, Williams 1984). An exception is Billen et al. (1980), obtaining an average conversion efficiency of $33 \%$.

Obviously, the measured uptake efficiency of ${ }^{14} \mathrm{C}$ labelled substrates will depend on the incubation period. Theoretically, the apparent conversion efficiency will be almost $100 \%$ after very short incubations. On the other hand, all the added label will eventually be respired in an unfractionated plankton sample, so at very long incubation periods the apparent conversion efficiency will approximate zero. Iturriaga \& Zsolnay (1981) observed a 2 to 3 -fold decrease in apparent conversion efficiency when the incubation period varied from 4 to $72 \mathrm{~h}$ (Table 1 ).

Another objection is the artificiality of the labelled substrates. Amino acids, particularly, are likely to enter anabolic pathways and are thus converted more efficiently than the variety of more or less refractory substrates which challenge planktonic bacteria in situ. In some experiments, however, short-term conversion

Table 1. Bacterioplankton carbon conversion efficiencies (\%) selected from the literature

\begin{tabular}{|c|c|c|c|c|}
\hline Mean & Range & Substrate & Method & Source \\
\hline 78 & $66-87$ & ${ }^{14} \mathrm{C}$-amino acids & $3.5-24 \mathrm{~h}$ incubation ${ }^{\mathrm{d}}$ & Williams (1970) \\
\hline 67 & $57-77$ & ${ }^{14} \mathrm{C}$-glucose & - $\quad-$ & - \\
\hline 69 & $40-97$ & ${ }^{14} \mathrm{C}$-amino acids & $2-6$ h incubation ${ }^{d}$ & Crawford et al. (1974) \\
\hline 77 & $69-82$ & ${ }^{14} \mathrm{C}$-exudates & $1 \mathrm{~h}$ incubation ${ }^{\mathrm{d}}$ & Iturriaga \& Hoppe (1977) \\
\hline 65 & $57-70$ & ${ }^{14} \mathrm{C}$-exudates & $3 \mathrm{~h}$ incubation ${ }^{d}$ & Bell \& Sakshaug (1980) \\
\hline 32 & $16-50$ & ${ }^{14} \mathrm{C}$-amino acids & $4 \mathrm{~h}$ incubation ${ }^{\mathrm{d}}$ & Billen et al. (1980) \\
\hline 35 & $20-50$ & ${ }^{14} \mathrm{C}-g l u c o s e$ & - & - \\
\hline$b$ & $40-69$ & ${ }^{14} \mathrm{C}-g l u c o s e$ & $4-72$ h incubation ${ }^{a}$ & Iturriaga \& Zsolnay (1981) \\
\hline b & $24-76$ & ${ }^{14} \mathrm{C}$-glycine & $-\quad-$ & - \\
\hline $\mathrm{b}$ & $10-25$ & ${ }^{14} \mathrm{C}$-glycollic acid & - & - \\
\hline 18 & $14-26$ & Phytoplankton hydrolysate & ${ }^{c}$ and ${ }^{d}$ & Sorokin (1971) \\
\hline 10 & $8-13$ & Phytoplankton detritus & ${ }^{\mathrm{c}}$ and ${ }^{\mathrm{e}}$ & Newell et al. $(1981)^{f}$ \\
\hline 13 & $9-24$ & Plant detritus & ${ }^{c}$ and $^{e}$ & Linley \& Newell (1984) \\
\hline 25 & $20-27$ & Natural (in situ) & ${ }^{d}$ and ${ }^{g}$ & Bell \& Kuparinen (1984) \\
\hline 23 & $17-27$ & Phytoplankton detritus & and ${ }^{\mathrm{d}}$ & Bauerfeind (1985) \\
\hline \multicolumn{5}{|c|}{$\begin{array}{l}{ }^{a} \text { Comparison of incorporated and respired }{ }^{14} \mathrm{C} \text { after incubation of natural bacterio } \\
\text { tions of labelled substrate } \\
\text { b Dependent on incubation period, cf. text } \\
{ }^{\mathrm{c}} \text { Bacterial net production estimated from microscopic determination of biovolume } \\
\mathrm{d} \text { Bacterial respiration determined as oxygen consumption } \\
\text { e Bacterial gross production determined as carbon substrate consumption } \\
{ }^{\mathrm{f}} \text { Recalculated in Linley et al. (1983) } \\
{ }^{\mathrm{g}} \text { Bacterial net production estimated from }{ }^{3} \mathrm{H} \text {-thymidine incorporation }\end{array}$} \\
\hline
\end{tabular}


efficiencies of about $70 \%$ have been reported for ${ }^{14} \mathrm{C}$ labelled exudates obtained from axenic algal cultures (Iturriaga \& Hoppe 1977, Bell \& Sakshaug 1980).

As another approach to the assessment of bacterial carbon conversion efficiency, a few authors have attempted to set up carbon balances for bacterioplankton populations. Newell and coworkers (Newell et al. 1981, Linley et al. 1983, Linley \& Newell 1984) studied degradation of plant detritus in mixed cultures of marine bacteria. Bacterial carbon yield was estimated from direct counts (Hobbie et al. 1977) and compared to loss of carbon substrate. Sorokin (1971) and Bauerfeind (1985) measured oxygen consumption and bacterial biovolume yield in bacterioplankton batches enriched with phytoplankton hydrolysate and detritus. Bell \& Kuparinen (1984) assessed bacterioplankton respiration and net production during a spring bloom in eutrophic Lake Erken, Sweden. These studies all indicate a bacterial growth yield in the range from 10 to $30 \%$. A common drawback is, however, that they are based on indirect methods and thus depend on assumed conversion factors, e.g. from oxygen consumption to carbon respiration, from ${ }^{3} \mathrm{H}$-thymidine incorporation to cell production and/or from biovolume to biomass. Recently, empirical calibrations have indicated that the generally used conversion factors from biovolume to biomass might have been underestimated (Bratbak \& Dundas 1984, Bratbak 1985, Bjørnsen in press). As a consequence, the estimated growth yields should be raised, but this might be compensated by other methodological biases. Thus, Bauerfeind (1985) measured respiration as oxygen consumption, even at low oxygen tensions. Linley \& Newell (1984) enriched bacterioplankton batches with powdered plant debris, but measured bacterial utilization as loss of dissolved organic carbon. In Sorokin (1971), a low conversion factor seems to be compensated by an empirical cell shrinkage factor of 2.5 .

Despite methodological problems, the cited studies all point to bacterial growth yields considerably below the conversion efficiencies, which have been measured with radiolabelled substrates. This indication is supported by the present study, in which respiration and net production were measured directly in carbon terms in bacterioplankton cultures grown on natural substrate.

\section{CONCLUSION}

It might be useful to distinguish between uptake efficiency and growth yield on the following grounds:

The uptake efficiency, measured by short term incubations with radiolabelled substrates, is relevant when bacterial gross uptake of phytoplankton exudates is calculated from fractionated ${ }^{14} \mathrm{C}$-incorporation mea- surements (Derenbach \& Williams 1974, Larsson \& Hagström, 1979, 1982, Cole et al. 1982). Ideally, the uptake efficiency should be measured on radiolabelled phytoplankton exudates (Iturriaga \& Hoppe 1977) and the incubation period should match that of the ${ }^{14} \mathrm{CO}_{2}$ incorporation experiment. Based on the present literature, 50 to $80 \%$ seems to be a realistic range of bacterioplankton uptake efficiency during a few hours' incubation.

The bacterial growth yield, defined as net production divided by substrate consumption, is required for the conversion of measured net production rates into substrate demands and is thus a crucial parameter for establishment of carbon budgets in pelagic ecosystems. The growth yield can be estimated from carbon balances for bacterioplankton populations in controlled systems. By this approach, the present study revealed bacterial growth yields of 18 to $23 \%$ at temperatures ranging from 6 to $15^{\circ} \mathrm{C}$. These results support the accumulated indications of bacterioplankton growth yields in the range from 10 to $30 \%$.

If such low growth yields are a general feature of planktonic bacteria, bacterial substrate demand and respiration have been underestimated in several studies, in which bacterial net production has been assessed by e.g. ${ }^{3} \mathrm{H}$-thymidine incorporation or frequency of dividing cells (Fuhrman \& Azam 1982, Larsson \& Hagström 1982). Furthermore, a reconsideration of bacterioplankton as even more important pelagic remineralizers might be needed.

Acknowledgements. This study was supported by the Danish Natural Science Research Council (journal number 11-4934) and by the Danish Environment Protection Agency. I am thankful to Dr. Morten Sondergaard for loan of a peristaltic pump, and to Dr. Bo Riemann, Dr Kaj Sand-Jensen and Professor Henry Blackburn for valuable suggestions on the manuscript.

\section{LITERATURE CITED}

Azam, F., Fenchel, T., Field, J. G., Gray, J. S., Meyer-Reil, L. A., Thingstad, F. (1983). The ecological role of watercolumn microbes in the sea. Mar. Ecol. Prog. Ser. 10: $257-263$

Bauerfeind, S. (1985). Degradation of phytoplankton detritus by bacteria: estimation of bacterial consumption and respiration in an oxygen chamber. Mar. Ecol. Prog. Ser 21: $27-36$

Bell, R. T., Kuparinen, J. (1984). Assessing phytoplankton and bacterioplankton production during early spring in lake Erken, Sweden. Appl. environ. Microbiol. 48: 1221-1230

Bell, W. H., Sakshaug, E. (1980). Bacterial utilization of algal extracellular products. 2. A kinetic study on natural populations. Limnol. Oceanogr. 25: 1021-1033

Billen, G., Joiris, C., Wijnant, J., Gillian, G. (1980). Concentrations and microbiological utilization of small organic molecules in the Scheldt Estuary, the Belgian Coastal zone and the English Channel. Estuar. coast. mar. Sci. 11: 279-294 
Bjornsen, P. K. (1986). Automatic determination of bacterioplankton biomass by means of image analysis. Appl. environ. Microbiol. 51: in press

Bratbak, G. (1985). Bacterial biovolume and biomass estimations. Appl environ. Microbiol. 49: 1488-1493

Bratbak, G., Dundas, I. (1984). Bacterial dry matter content and biomass estimations. Appl. environ. Microbiol. 48: $755-757$

Calow, P. (1977). Conversion efficiencies in heterotrophic organisms. Biol. Rev. 52: 385-409

Cole, J. J., Likens, G. E., Strayer, D. (1982). Photosynthetically produced dissolved organic carbon: an important carbon source for planktonic bacteria. Limnol. Oceanogr. 27 : 1080-1090

Crawford, C. C., Hobbie, G. E., Webb, K. L. (1974). The utilization of dissolved free amino acids by estuarine organisms. Ecology 55: 551-563

Derenbach, J. B., Williams, P. J. leB. (1974). Autotrophic and bacterial production: Fractionation of plankton populations by differential filtration. Mar. Biol. 25: 263-269

Ferguson, R. L., Rublee, P. (1976). Contribution of bacteria to standing crop of coastal plankton. Limnol. Oceanogr. 21: 141-145

Furhman, J. A., Azam, F. (1982). Thymidine incorporation as a measure of bacterioplankton production in marine surface waters. Mar. Biol. 66: 109-120

Furhman, J. A., McManus, G. B. (1984). Do bacteria-sized marine eukaryotes consume significant bacterial production? Nature, Lond. 310: 1257-1260

Gocke, K. (1976). Respiration von gelösten organischen Verbindungen durch natürliche MikroorganismenPopulationen. Ein Vergleich zwischen verschiedenen Biotopen. Mar. Biol 35: 375-383

Hagström, A.., Ammerman, J. W., Heinrichs, S., Azam, F (1984). Bacterioplankton growth in seawater. Il. Organic matter utilization during steady state growth in seawater cultures. Mar. Ecol. Prog. Ser. 18: 41-48

Hobbie, J. E., Daley, R. J., Jasper, S. (1977). Use of Nuclepore filters for counting bacteria by epifluorescence microscopy. Appl, environ. Microbiol. 33: 1225-1228

Iturriaga, R., Hoppe, H.-G. (1977). Observations of heterotrophic activity on photoassimilated matter. Mar Biol. 40 101-108

Iturriaga, R., Zsolnay, A. (1981). Transformation of some dissolved organic compounds by a natural heterotrophic population. Mar. Biol. 62: 125-129

Joint, I. R., Morris, R. J. (1982). The role of bacteria in the turnover of organic matter in the sea. Oceanogr. mar. Biol. A. Rev. 20: $65-118$

Keller, M. D., Mague, T. H., Badenhausen, M., Glover, H. E. (1982). Seasonal variations in the production and consumption of amino acids by coastal microplankton. Estuar. coast. mar. Sci. 15: 301-315
Larsson, U., Hagström, А.. (1979). Phytoplankton exudate release as an energy source for the growth of pelagic bacteria. Mar. Biol. 52: 199-206

Larsson, U., Hagström, A.. (1982). Fractionated phytoplankton production, exudate release and bacterial production in a Baltic eutrophication gradient. Mar. Biol. 67: 57-70

Lindeman, R. L. (1942). The tropho-dynamic aspect of ecology. Ecology 23: 399-418

Linley, E. A. S., Newell, R. C., Lucas, M. I. (1983). Quantitative relationships between phytoplankton, bacteria and heterotrophic microflagellates in shelf waters. Mar. Ecol. Prog. Ser. 12: 77-89

Linley, E. A. S., Newell, R. C. (1984). Estimates of bacterial growth yields based on plant detritus. Bull. mar. Sci. 35: $409-425$

Newell, R. C., Lucas, M. I., Linley, E. A. S. (1981). Rate of degradation and efficiency of conversion of phytoplankton debris by marine micro-organisms. Mar. Ecol. Prog. Ser. 6: 123-136

Pomeroy, L. R. (1974). The ocean's food web, a changing paradigm. Bioscience 24: 499-504

Slater, J. H. (1979). Principles of microbial behaviour in ecosystems. In: Lynch, J. M., Poole, N. J. (ed.) Microbial ecology, a conceptual approach. Blackwell, Oxford, p. 5-63

Sorokin, Y. I. (1971). On the role of bacteria in the productivity of tropical oceanic waters. Int. Revue. ges. Hydrobiol. 56: $1-48$

Steele, J. H. (1974). The structure of marine ecosystems. Harvard Univ, Press, Cambridge

Stevenson, L. H. (1978). A case for bacterial dormancy in aquatic systems. Microb. Ecol. 4: 127-133

Taylor, G. T. (1982). The role of pelagic heterotrophic protozod in nutrient recycling: a review. Annls Inst. océanogr. Paris 58: 227-241

Watson, S. W., Novitsky, T. W., Quinby, H. L., Valois, F. W. (1977). Determination of bacterial number and biomass in the marine environment. Appl. environ. Microbiol. 33: 940-946

Williams, P. J. leB. (1970). Heterotrophic utilization of dissolved organic compounds in the sea. I. Size distribution of population and relationship between respiration and incorporation of growth substrates. J. mar. biol. Ass. U. K. 50: 859-870

Williams, P. J. leB. (1981). Incorporation of microheterotrophic processes into the classical paradigm of the marine food web. Kieler Meeresforsch. 5: 1-28

Williams, P. J. leB. (1984). Bacterial production in the marine food chain: the emperor's new suit of clothes? In: Hobbie, J. E., Williams, P. J. leB. (ed.) Heterotrophic processes in the sea. Plenum Press, p. 271-299

ZoBell, C. E. (1946). Marine microbiology. A monograph on hydrobacteriology. Chronica Botanica Co., Waltham 